\title{
Fra Beethovens skrivepult i Wien til magasinerne i København
}

En manuskriptkopi af Beethovens Missa solemnis

i Det Kongelige Bibliotek

afforskningsprofessor emeritus

Niels Krabbe, Det Kongelige Bibliotek

S iden slutningen af 1990'erne har det været kendt inden for den internationale Beethovenforskning, at Det Kongelige Bibliotek ejer en håndskreven kopi af Beethovens Grosse Messe (i eftertiden kendt som Missa solemnis), som han for det første selv har foretaget visse rettelser $\mathrm{i}$, og som han for det andet selv har foranlediget sendt til Danmark. ${ }^{1}$ Selve kopien har befundet sig i Danmark siden 1824 , til at begynde med formentlig som en del af kongens arkiv; senere blev den i midten af 1800-tallet eller lidt tidligere indlemmet i Henrik Rungs private samling af tryk og manuskripter, og endelig blev den overdraget til Det Kongelige Bibliotek i 1955 som en del af det omfattende H. \& Fr. Rungs Musikarkiv, som Frederik Rung selv havde foranlediget katalogiseret. Manuskriptet har således været kendt og registreret i godt 175 år, men mig bekendt har dets tilknytning til Beethovens person aldrig været omtalt i nogen dansk sammenhæng uagtet den store interesse, der i øvrigt har været for H. \& Fr. Rungs Musikarkiv, og uagtet den kildemæssige betydning, det har haft for arbejdet med den kritisk-videnskabelige udgave af Beethovens værker, hvor bindet med Missa solemnis udkom i 2000. ${ }^{2}$

Manuskriptets fysiske tilstand med løs ryg

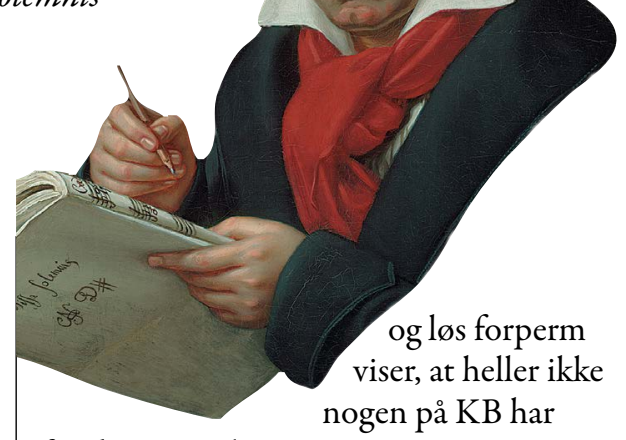

fundet manuskriptet så interessant, at man har villet ofre en særlig bevaringsindsats på det. Alle har formentlig tænkt, at der her var tale om en traditionel professionel kopi fra lidt før midten af det 19. århundrede af et af Beethovens værker.

Ydermere er manuskriptet direkte og indirekte omtalt i et enkelt af Beethovens breve og adskillige gange i hans konversationshæfter fra årene 1822-24 (se nedenfor); men bortset fra nogle forgæves undersøgelser i Rigsarkivet af musikforskeren William Behrend i 1909, har øjensynligt ingen her i landet forsøgt at finde frem til, om genstanden for disse omtaler skulle befinde sig i Danmark. Og dette, som antydet, til trods for, at manuskriptet siden 2000 har optrådt som kilde $\mathbf{D}^{6} \mathrm{i}$ den samlede udgave af Missa solemnis. ${ }^{3}$ Efterfølgende præsentation kan således ikke gøre krav på nogen form for "nyopdagelse" fra undertegnedes side, men er alene en præsentation af manuskriptet, dets baggrund, proveniens og betydning og dermed et forslag om, at manuskriptet fremover rykker op i graderne fra at være en "interessant professionel kopi af Missa solemnis" til at blive et af "musiksamlin- 


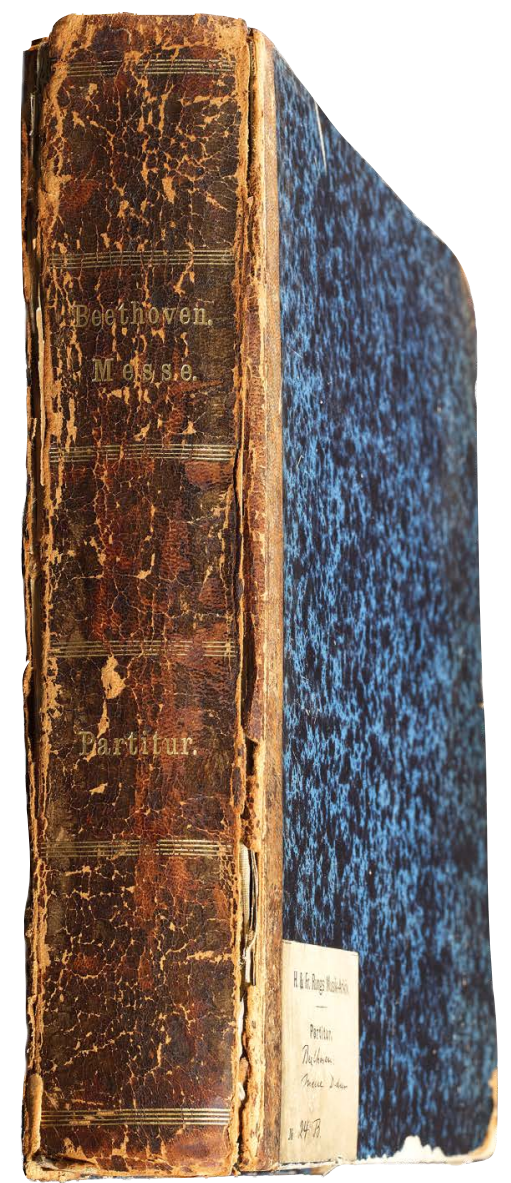

Ill. 1: Kopi af Beethovens Grosse Messe $i$ H.\& Fr. Rungs Musikarkiv i Det Kongelige Bibliotek. Foto: Fotografisk Atelier.

gens klenodier" - det sidste i kraft af, at Beethoven selv har haft fingre i det.

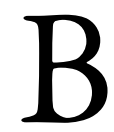
aggrunden for, at "vores" manuskript går tilbage til Beethoven personligt, er indgående beskrevet såvel i Anton Schindlers Beethoven-biografi fra 1840 som i fjerde bind af A.W. Thayers store monografi om mesteren fra årene 1866-1908 - førstnævnte uden at inddrage det danske eksemplar, sidstnævnte med en enkelt sætning, der omtaler et muligt eksemplar i Danmark: "wohl aber subskribierte der König von Dänemark; über die Einzelheiten sind wir nicht genauere unterrichtet." ${ }^{4}$ Disse "Einzelheiten" vil blive uddybet i det følgende.

Men først en kort omtale af forhistorien. Beethoven skrev sit indtil da mest omfangsrige værk, Missa solemnis opus 123, i årene 1819-1823, ${ }^{5}$ altså samtidig med de tre sidste klaversonater opus 109, 110 og 111 og den store 9 . symfoni med inddragelse af Schillers ode, "An die Freude", i fjerde sats - værker, der alle betegner et skift i Beethovens overordnede tilgang til sin kunst væk fra "det heroiske" (som det udmønter sig i værker værkerne fra c. 1803 til c. 1812) i retning af "det religiøse". Mens den niende symfoni straks fik en central placering i den beethovenske kanon, forholdt det sig - og forholder det sig - mere problematisk med Missa solemnis. Beethoven understregede selv, at værket ikke primært er tænkt i en liturgisk sammenhæng (det ville i så fald blive en lang gudstjeneste, hvis der også skulle være plads til læsninger, prædiken og bønner), men også er tænkt til koncertopførelse. I et brev fra 23. januar 1823 udtrykte han dette således: "Daßelbe [altså messen] ist eine große solenne Messe [...] in Partitur, welche auch als großes Oratorium gebraucht werden kann". ${ }^{6}$ I sammenhæng med den historie, der er beskrevet i nærværende artikel, er netop denne bemærkning af betydning: havde det været et rent liturgisk værk, havde det næppe givet mening at fremsende et salgstilbud til den protestantiske Frederik 6.

Kort tid efter at have afsluttet sin store komposition fattede Beethoven den beslutning, at han ville forsøge at få en 
række europæiske hoffer og fyrster til at subskribere på en håndskreven kopi af sin nye messe, samtidig med at han fastslog (måske lidt opportunistisk), at værket aldrig ville blive trykt. Det blev det dog, men først fire år senere hos musikforlaget Schott i Mainz. Beethovens bevæggrunde var dels ønsket om, at hans nye værk fik udbredelse i de toneangivende fyrstelige kredse rundt om i Europa, dels at han på dette tidspunkt var i økonomiske vanskeligheder og derfor havde hårdt brug for de 50 dukater, som han forlangte for hver bestilling, der indløb. ${ }^{7}$

nton Schindler - Beethovens
nærmeste medarbejder og
famulus gennem de seneste knap 10 år af hans liv og forfatter til en stærkt omdiskuteret biografi om mesteren, hvis første udgave forelå i 1840 - gengiver Beethovens plan således:

"Beethoven havde længe haft planer om at tilbyde $\sin$ Messe som manuskript i subskription til samtlige større eller mindre hoffer mod et honorar på 50 dukater pr. eksemplar. Han havde helt og holdent lagt udførelsen af denne forretning, der var behæftet med et stort antal formaliteter og omstændigheder, i mine hænder. I den tyske invitations-skrivelse betegnede han værket som sit mest vellykkede - i den skrivelse der tilflød det franske hof som sit mest fuldendte arbejde; samtlige skrivelser indeholdt den udtrykkelige bemærkning, at værket også kunne anvendes som oratorium, det vil sige i koncertsalen".

I det følgende beskriver Schindler herefter, hvorledes han (Schindler) påtog sig det store arbejde at rundsende subskriptionstilbud til de forskellige fyrstehoffer, og hvordan otte af skrivelserne resulterede i en bestilling på værket, således at hele projektet indbragte i alt 400 dukater til Beethoven. Schindler bemærker tørt, at denne sum næppe har hjulpet Beethoven meget $i$ hans betrængte $ø$ konomiske situation, når man betænker, at han har måttet bekoste en professionel kopi til hver af subskribenterne samt foranstalte og delvis selv deltage i en korrekturlæsning af de afsendte eksemplarer. Men trods den fyldige omtale af projektet hos Schindler - og ikke mindst hans egen prisværdige indsats i dets udførelse - nævner Schindler ikke et ord om henvendelsen til Frederik 6., der som nævnt resulterede i en bestilling. Måske kan årsagen til denne undladelse være, at han øjensynligt har trukket netop denne henvendelse lidt længere ud, end Beethoven har brudt sig om - ja nærmest syltet opgaven. Denne proces kan vi følge gennem de såkaldte "konversationshæfter", som skal omtales i det følgende, men samtidig er Schindlers slendrian måske grunden til, at netop det danske eksemplar er det af subskriptionseksemplarerne, der af eftertiden har fået den største kildemæssige værdi, fordi Beethoven selv kunne gennemse og rette i dette sidste af de rundsendte kopier. En tilsvarende indsats fra Beethovens side i forbindelse med de øvrige fem bevarede subskriptionseksemplarer synes ikke at have fundet sted.'

Inden vi mere indgående skal komme ind på den konkrete historie bag det danske eksemplar - blandt andet belyst gennem konversationshæfterne - skal det kort anføres, at også den første mere videnskabeligt funderede og vel også mere "objektive" Beethoven-biografi af A.W. Thayer, der udkom delvist posthumt i årene 1866-1908, naturligvis har en indgående beskrivelse af Beethovens reklamefremstød omkring sin nye Missa. 
Også her understreges det, at projektet bla. udsprang af hans økonomiske situation som følge af udgifter i forbindelse med formynderskabet for hans nevø og hans egen sundhedstilstand - forhold, som begge medvirkede til en nedsættelse af den kunstneriske produktivitet med deraf følgende indtjeningsmuligheder. I Thayers lange redegørelse for hele forløbet af sagen om de mange subskriptionsanmodninger og resultatet af henvendelserne, omtales henvendelsen til Frederik 6. (og dermed indirekte det danske eksemplar) som nævnt ovenfor kun med den ene sætning:

"Der Einladung an den schwedischen Hof legte Beethoven, nach Schindler, ein sorgsam abgefaßtes Schreiben an den König bei; doch kam von dort keine Erwiderung. Wohl aber subskribierte der König von Dänemark; über Einzelheiten sind wir nicht genauer unterrichtet". ${ }^{10}$

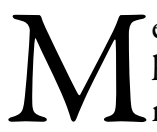
en tilbage til konversationshæfterne - og deres indblik i maskinrummet, så at sige. Det er velkendt, at Beethoven begyndte at få vanskeligheder med hørelsen allerede omkring $1802,{ }^{11}$ og i de sidste godt ti år af sit liv kunne han absolut intet høre. For at fastholde en form for kommunikation med sine omgivelser måtte han fra o. 1818 derfor konstant have små hæfter ved hånden, hvori hans samtalepartnere kunne nedskrive deres bemærkninger til Beethoven - i visse tilfælde suppleret med Beethovens egne bemærkninger og svar. Ved sin død efterlod han sig omkring 400 sådanne hæfter, hvoraf ca. 140 er blevet bevaret for eftertiden, idet en betydelig del af materialet enten er gået tabt eller er blevet destrueret af Anton Schindler. På trods af de hastigt nedkradsede bemærkninger og hæfternes af indlysende grunde usammenhængende karakter giver de naturligvis et helt enestående indblik i sider af mesterens hverdag og den emnekreds, venner og besøgende har diskuteret med ham. Der er blot den hage ved det, at netop Schindler - altså en af hovedkilderne til vores viden om Beethoven og en af de hyppigst optrædende i konversationshæfterne - har fusket med materialet. Dels har han som sagt destrueret en del af de 400 hæfter efter at have benyttet dem til sin egen Beethoven biografi, dels har han foretaget rettelser og tilføjelser i hæfterne efter Beethovens død, men på en måde, så det skulle se ud som om de pågældende bemærkninger var en del af den løbende "konversation" med Beethoven. Hans motiver lader til at have været et ønske om at placere sig selv som den helt centrale person i overleveringen af arven efter Beethoven og den, som mere end nogen anden stod i tæt kontakt med komponisten. Afsløringen af dette falskneri fandt sted i forbindelse med udgivelsen af de samlede konversationshæfter, påbegyndt omkring 1970 og under stor opmærksomhed kundgjort som en sensation ved en international Beethoven-kongres i Berlin i 1977. ${ }^{12}$ Afsløringen af falsknerierne byggede på to forhold. For det første kunne man påvise, at de mange indførsler af Schindler ganske vist fremstod $i$ hans autentiske håndskrift, men håndskriften faldt tydeligvis $i$ to kategorier, den ene Schindlers hånd fra årene omkring 1820 (altså de år, hvor han virkede som Beethovens sekretær), og den anden Schindlers hånd fra 1840erne - altså mere end 10 år efter Beethovens død, mens han arbejdede med at "tilrettelægge" (eller måske rettere "tilrette") Beethoven-arven for eftertiden. For det 
andet viste det sig, at en række indførsler i Schindlers hånd forudsatte viden om en række faktuelle forhold og begivenheder, som på det angivne tidspunkt i hæfternes kronologi endnu ikke havde fundet sted! Det siger sig selv, at opdagelsen af Schindlers forfalskninger var en bombe under mere end 100 års Beethoven-forskning, dels fordi det såede tvivl om en række detaljer i hæfterne (og dermed problematiserede en række "strukturer" og nøglebegreber i Beethoven-receptionen), dels fordi der manglede så mange af de hæfter, der havde eksisteret ved Beethovens død, og endelig fordi hovedparten af det 19. og tidlige 20.århundredes Beethoven forskning i høj grad byggede på Schindler og hans påståede centrale position i forhold til Beethoven.

Baggrunden for i nærværende sammenhæng at nævne Schindlers lidt flossede moral i forhold til disse vigtige kilder er, at vores viden om forhistorien for det danske manuskript ikke alene bygger på de to ovennævnte biografier, men - som det vil fremgå - ikke mindst på en række indførsler af Schindler i konversationshæfterne. Ingen af disse Schindler-bemærkninger hører dog til blandt de "uægte"! 13

Efterfølgende skema anfører de indførsler i konversationshæfterne (næsten udelukkende af Schindler), der specielt vedrører Beethovens/Schindlers henvendelse til det danske hof:

$\frac{\text { Tekst }}{\text { Hefte } 21 \text { - 27.-29. januar } 1823}$

Schindler:

"denn ich war heute schon beym $D \ddot{a}$ nischen Gesandten, der mir sagte, daß man directe an König schreiben müßen, indem er keine derley Aufträge annehmen darf. Das könne[n] wir thun, $\mathrm{u}$ [nd] ich ersuche, daß er es mit den Depeschen abschickt."

\section{Schindler:}

"dieser H[err] sagte nur, daß Sie sich deßhalb gerade an den Hof wenden müßen, indem sie keine Vollmacht hätten.”

Schindler:

"Baden, Württemberg, Bayern, Sachsen, Mecklenburg, Preußen, Rußland, Weimar, einige fallen mir nicht ein, geschrieben ist aber alles."

\section{Kommentar}

Joachim Friedrich Graf von Bernstorff, Danmarks repræsentant under Wienerkongressen og efterfølgende dansk gesandt i Wien fra 1816.

Frederik 6.

\section{Bernstorff}

I Beethovens lommebog har Schindler ydermere eksplicit skrevet, at han 4 . februar 1823 har leveret subskriptionsindbydelsen til en række legationer, herunder den danske. ${ }^{14}$ 
Hefte 22 - 7.-11. februar 1823

Schindler:

"den Dichter Fürst kenne Sie doch, er ist aus Kopenhagen, $\mathrm{u}[\mathrm{nd}]$ schreibt an seine Freunde bey Hof in casu der Messe"

Hefte 26 - 4. marts 1823

Schindler:

“jetzt muß ich Ihnen bekennen, daß unter allen Gesandten, der dänische der einzige war, der das Schreiben nicht angenom [m] en hat. Ich geb es daher gleich auf die Post; hätte Ihnen nichts davon gesagt, jetzt aber durch Siboni können Sie das in Erwähnung bringen, $\mathrm{u}$ [nd] es wird den König gewiß ergreifen.”

"er wird gewiß von seinem Hofe den Auftrag bekom[m]en das Werk zu übersenden."

Hefte 27 - 20.-25. marts 1823

Schindler

"ein Virtuos auf dem Waldhorn auf der Durchreise hier geht zur Kapelle nach Koppenhagen, vielleicht wäre es Ihnen gefällig, einen Brief an Siboni mitzugeben, er geht Dienstag weg."

[15 sider senere i samme hæfte, fem punkter, der har karakter af en huskeseddel; sidste punkt:]

Beethoven:

"postwagen donnerstag Siboni"
Nicolai Nathan Fürst (1779-1857), dansk skribent, virkede i Wien fra 1814 til 1824, rejste derefter til Paris for siden at vende tilbage til Wien. Skrev en række artikler for såvel danske som østrigske litterære tidsskrifter. Traf bl.a. Oehlenschläger i Wien og blev dennes agent i Wien. ${ }^{15}$

Giuseppe Siboni, fra 1819 syngemester i København; virkede i Wien som fejret operasanger på Kärthnerthortheater fra 1810-1814. Havde i 1814 overværet opførelsen af Beethovens 7. symfoni og ved den lejlighed medvirket i hans Terzet for sopran, tenor og bas med orkester, Tremate, empii. Siboni havde været på et kort ophold i Wien i foråret $1823 .{ }^{16}$

Selvom det ikke fremgår uomtvisteligt, er der næppe tvivl om, at også denne indførsel har med subskriptions-indbydelsen til det danske hof at gøre; så meget desto mere, som de foregående indførsler handler om hele sagen med rundsendelse af skrivelser til de europæiske hoffer. 
Hafte 30 - 21.-26. april 1823

Schindler:

"Graf Bernstorf hat es "das Brief"] aber

Meningen ikke ganske klar. von Fürst angenom $[\mathrm{m}]$ en u[nd] expedirt" $-$

"er scheint ein strenger Geschäftsmann zu seyn er excusirte sich, daß er sich in privat Sachen nicht mischen dürfe, allein Fürst steht auf dem vertrautesten Fuß mit ihm, dort war's möglich. ich zweifle, daß seine Wünsche hier befriediget werden"

Hafte 63 - 23.-30. april 1824

Beethoven:

"wegen Siboni Dänisch.[e] Gesands. [chaft]"

Schindler:

"ich erwarte aber von Bernstorf keine günstige Antwort, indem Sie sich erinnern, daß er Ihnen sagen ließ durch mich, er mische sich nicht in die privaten Sachen des Königs, denn er ist rasend furchtsam - allein hören will ich, was er itzt auf dieses antwortet."

Schindler:

"bey Dänemark war ich heute schon Mahl. Se Hochgeboren lagen um halb 12 Uhr noch im Bette."

Hafte 67 - slutningen af maj 1824

Beethoven:

[sidste linje i huskeliste]:

"Siboni Script"

Neffe:

"Er hat ja selbst geantwortet daß der König 50 *” [=dukater] 
Af disse førstehåndsoptegnelser, suppleret med Schindlers fortælling i hans biografi (og med de forbehold, som Schindlers hele adfærd og selvpromovering i sit forhold til Beethoven nødvendiggør), kan vi udlede følgende om begivenhedsforløbet forud for manuskriptkopiens ankomst til Danmark formentlig engang i sensommeren 1824:

I begyndelsen af 1823 besluttede Beethoven at henvende sig til en række europæiske fyrstehuse med en opfordring om, at de afgav bestilling på en kopi af hans nye Missa mod en betaling på 50 dukater. Anton Schindler udformede en række enslydende skrivelser, som Beethoven herefter underskrev, og ekspederede dem enten direkte eller via de pågældende landes gesandtskaber i Wien. I slutningen af januar 1823 forsøgte Schindler via den danske gesandt grev J.F. Bernstorff at rette henvendelse til den danske konge, Frederik 6.; denne havde allerede været i Wien under Wienerkongressen og angiveligt købt forskellige musikalier af Mozart og Beethoven. ${ }^{17}$ Bernstorff oplyste til Schindler, at en sådan henvendelse skulle gå direkte til hoffet og ikke via gesandten; Schindler skriver, at det skal han nok tage sig af (hæfte 21). Et par dage senere hævder han, at han nu har afsendt alle subskriptionsindbydelserne (hæfte 21). Efter endnu en uge făr Schindler en ny ide, nemlig at forsøge at få den danske litterat Nikolay Anthon Fürst til at fungere som mellemmand mellem Wien og København (hæfte 22). Knap en måned senere, d. 4 marts, må Schindler gå til bekendelse og fortælle Beethoven, at trods de tidligere forsikringer er brevet til det danske hof som det eneste af de mange subskriptionstilbud til de europæiske fyrstehoffer endnu ikke afsendt. Egentlig ville han ikke have fortalt dette til Beethoven tidligere (!), men nu vil han prøve at få Siboni til at formidle kontakten, og han vil nok kunne bevæge kongen til at sige ja til tilbuddet om en kopi af messen (hæfte 26). Fjorten dage senere er der stadig ikke sket noget, og nu foreslår Schindler, at man "på tirsdag" sender et brev til Siboni med en omrejsende waldhornist, som skal til København (hæfte 27); fjorten sider senere i samme hæfter er anført en påmindelse om postvognen og et brev til Siboni. Så går der igen en måneds tid. Nu meddeler Schindler at grev Bernstorff, som er en streng herre, er blevet overtalt af den danske skribent Nikolay Nathan Fürst til at ekspedere sagen (hæfte 30). Så går der et helt år, uden at vi hører noget til sagen. I slutningen af april 1824 dukker den op igen i konversationshæfterne. Nu tvivler Schindler på, at Bernstorff kan bidrage til sagens ekspedition, for han blander sig nødig $i$ kongens private anliggender. Schindler forsikrer dog, at han nok skal forhøre sig hos Bernstorff, men besøget hos denne fører ikke til noget, for Schindler må konstatere, at gesandten kl. halv tolv endnu ikke er stået op (hæfte 63)! En måned senere (i slutningen af maj 1824) finder vi så den sidste indførsel om sagen (hæfte 67), som måske kan tolkes således, at Siboni nu har foranlediget, at Beethovens henvendelse er kommet Frederik 6. i hænde, og at den danske konge har sagt ja tak til tilbuddet; i det pågældende konversationshæfte anfører Beethovens Nevø umiddelbart efter en lidt kryptisk bemærkning om 50 dukater - en bemærkning, som man må formode vedrører hele sagen om Missa solemnis, selvom dette ikke er ganske klart. Hvordan og hvornår selve manuskriptet herefter er fragtet 


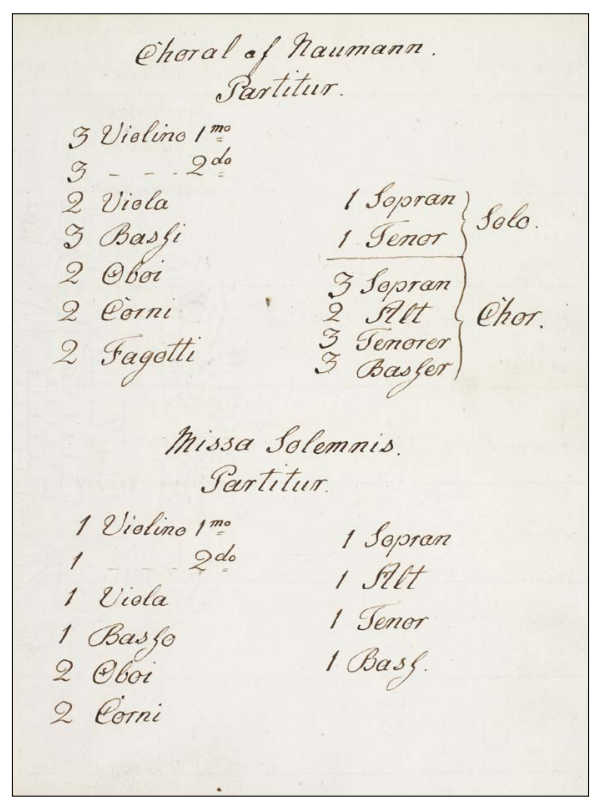

Ill. 2: Indforsel af anonym Missa Solemnis i Hofkatalogen fra 1826, uden komponistangivelse, som - selvom man kunne vente det viser sig ikke at vere identisk med Beethovens vark, men som derimod refererer til en belt anden, anonym, messe $i$ Gieddes Samling $i$ Det Kongelige Bibliotek.

til København fremgår ikke af de hidtil kendte kilder.

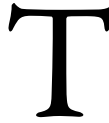
ilsyneladende er selve korrespondancen mellem Wien og København gået tabt; ej heller er der vidnesbyrd om, at nogen ved hoffet har været specielt opmærksom på dets tilknytningsforhold til Beethoven selv. I hvert fald er der ingen bemærkninger i manuskriptet - hverken i form af et kongelig ejermærke eller i form af angivelser af manuskriptets proveniens. Heller ikke indbindingen er prangende og er måske først udført efter at manuskriptet var blevet overført fra hoffets samling til Frederik Rungs samling, således som der er gjort rede for i det følgende.

Ikke desto mindre kunne man formode, at manuskriptet ved sin ankomst til Danmark blev indlemmet og efterfølgende registreret i hoffets samling af musikalier. Efter slotsbranden i 1794, hvor store dele af hoffets musiksamlinger gik tabt, gjorde man sig store anstrengelser for at genopbygge en erstatning for den tabte musiksamling. I 1826 - altså to år efter modtagelsen af Beethoven-manuskriptet - påbegyndtes således en løbende katalog over hoffets musikalier i form af to små kvarthæfter, der begge er bevaret i biblioteket (Ny kgl. Samling 3503 I-II, $\left.4^{\circ}\right){ }^{18}$ Katalogerne bærer følgende titler:

(Katalog 1): Fortegnelse over Kirke Musikerne som ere i det Kongelige Archiv 1826

(Katalog 2): Fortegnelse over de Geistlige og en deel andre Musikker tilhørende det kongelige Hofarkiv.

Selvom katalog 2 er udateret, viser en sammenligning mellem de to kataloger både med hensyn til indhold og kopisternes håndskrift, at katalog $2 \mathrm{er}$ en udvidet afskrift af den daterede Katalog 1. Katalogerne indeholder poster på værker der stammer såvel fra før som efter 1826 , og katalogerne er således ført løbende en række år efter 1826. ${ }^{19} \mathrm{I}$ denne katalog kunne man derfor vente at finde en optegnelse om vores Beethoven-manuskript; ved første øjekast er der også noget, der tyder på, at det netop er tilfældet. Efter afslutningen på den første del af Katalog 2, der som nævnt er en direkte afskrift af katalog 1, følger efter en række blanke sider en ny, systematisk fortegnelse med titlen med Fortegnelse over endeel Musikker tilhørende det kongelige Hofarkiv, altså 
en titel, der næsten er identisk med titlen for hele Katalog 2. "Gruppe 18" i denne del af katalogen registrerer en række vokalværker af bl.a. Haydn, Scarlatti og Naumann og som afsluttende værk i denne gruppe finder vi titlen Missa Solemnis, uden komponistangivelse og uden proveniensangivelse, men alene med angivelse af besætningen: strygere, 2 oboer, 2 horn samt firestemmigt blandet kor. ${ }^{20}$

Det havde været nærliggende at antage, at der her er tale om en registrering af netop Beethovens værk, altså det eksemplar, som han selv få år forinden havde sendt til Frederik 6., og som nu befinder sig i KBs samlinger. Blot måtte man i så fald undre sig over, at penneføreren bag katalogen ikke havde fundet anledning til at anføre komponistens navn. Dels indeholder katalogen allerede yderligere et værk af Beethoven (Kristus på Oliebjerget med komponistangivelse), dels var Beethoven på dette tidspunkt et kendt navn overalt i Europa, så værket - med eksplicit nævnelse af Beethovens navn - ville have kastet glans over det danske hof. Spørgsmålet kompliceres yderligere af katalogens titel på værket, Missa Solemnis. Den danske kopi, ligesom de øvrige fem subskriptionseksemplarer, har titlen Grosse Messe; andre kilder anvender titlerne Messe, Missa, eller Messe solenelle, men ingen af kilderne bruger titlen Missa solemnis. Selvom Beethoven selv i et konversationshæfte fra 1820 omtaler det igangværende værk som Missa solemnis og anmoder maleren Joseph Karl Stieler om at bruge netop denne titel på sit berømte maleri af Beethoven fra 1820 (Missa solemnis aus D\#, se illustration på næste side), er det næppe sandsynligt, at denne betegnelse allerede i 1826 var kendt i Danmark, hvilket yderligere viser, at Hofkatalogens indførsel ikke refererer til Beethovens manuskript. ${ }^{21}$ Der er således ingen tvivl om, at Beethovens messe ikke, som ventet, optræder i hofkatalogen, og en nærmere undersøgelse $i$ andre af bibliotekets samlinger viser da også, at den nævnte Missa solemnis dækker over et helt andet værk, nemlig en anonym Missa Solemnis i partitur og stemmer, der oprindeligt stammer fra Gieddes samling i KB. ${ }^{22}$

Når man tager alle Beethovens anstrengelser for at komme i kontakt med den danske konge i betragtning og efterfølgende konstaterer, at anstrengelserne på den ene eller anden måde bar frugt (idet manuskriptet jo rent faktisk blev sendt til Danmark), må man undre sig over, at der ikke foreligger nogen form for vidnesbyrd om dets skæbne i den tid, det har været i hoffets varetægt. Og specielt må man, som antydet ovenfor, undre sig over, at det ikke blev registreret i Hofkatalogen fra 1826, som blev påbegyndt kun to år efter, at manuskriptet var kommet til Danmark.

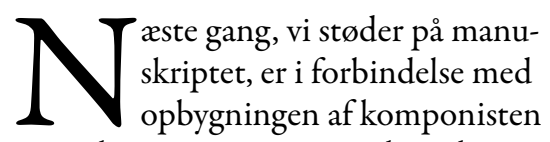
Henrik Rungs private musiksamling, som kom til at indgå i det, der siden fik det officielle navn $H$. \& Fr. Rungs Musikar$k i v$. Det er velkendt, at denne samling primært bestod af italiensk renæssancemusik, indsamlet af Rung selv på rejser til Italien, med en musik, som senere dannede kærnen i repertoiret i den af Rung grundlagte musikforening, Caciliaforeningen. ${ }^{23}$ Men også materiale fra det ovenfor omtalte hofarkiv synes at have indgået $\mathrm{i}$ samlingen, hvilket kan være af betydning i forsøget på at spore Beethoven- manuskriptets historie. I Carl Thranes bog om Henrik Rung hedder det: 


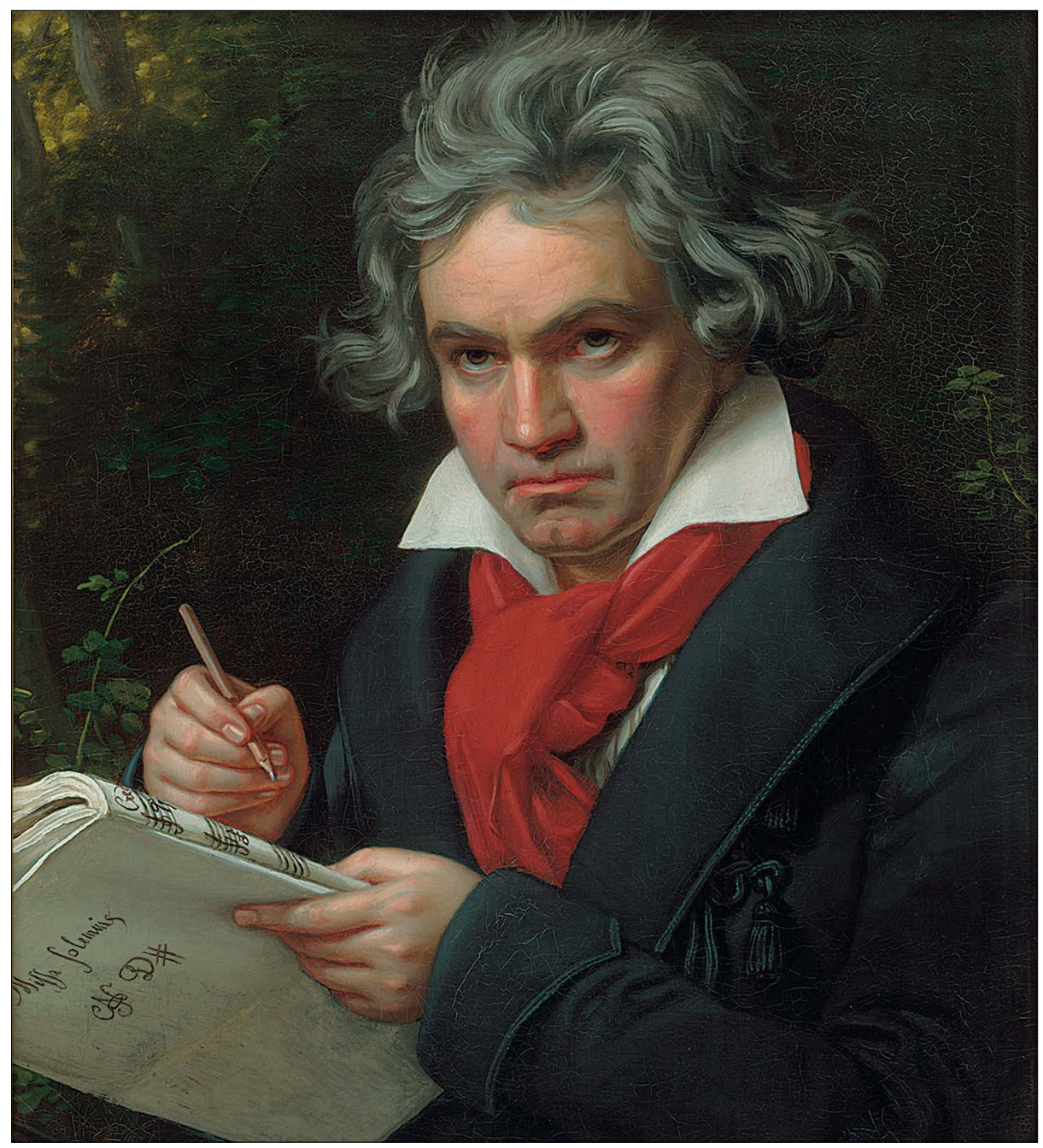

Ill. 3: Portret af Beethoven, malet i april 1820 af Karl Joseph Stieler, mens Beethoven var i ferd med at komponere varket. Det fremgar afkonversationshafte 11 fra april 1820, at Beethoven udtrykkeligt har bedt om, at der på billedets nodeark stär anfort "Missa solemnis aus D" (se note 21). Beethoven-Haus Bonn.

"Han [Henrik Rung] kom en Dag meget fornøjet hjem med nogle "gamle Noder" og fortalte, at han havde været oppe på Christiansborg Slots - Slotskirkens? Loft for at undersøge nogle Musikalier, som laa der, og fundet disse Ting, som han havde faaet Lov til at beholde. Det var Partituret til Glucks Festspil (Serenata) "La contesa dei nurmi ("Gudernes Trætte”), komponeret og opført i Kjøbenhavn i Anledning af Christian VII's Fødsel." ${ }^{24}$ 
I gen kan vi kun gætte os til, hvad der måtte ligge bag denne kortfattede beretning, men meget tyder på, at det netop er noderne fra Hofarkivet, som Henrik Rung har gennemset, eftersom vi ved, at det omtalte eksemplar af Glucks værk indgik i hofarkivet. ${ }^{25}$ Måske har han ved den lejlighed set kopien af Beethovens værk og taget det med sig (eftersom det jo efter Henrik Rungs død indgik i $H$. \& Fr. Rungs Musikarkiv), men med sin særlige interesse for "gammel" musik har hans begejstring for fundet kun omfattet Glucks værk, mens Beethoven-kopien måske bare er taget med i købet og lagt i bunken med andre værker i Rungs samling. Tydeligvis har Henrik Rung i hvert fald ikke været klar over kopiens tætte forhold til Beethoven selv. ${ }^{26}$ Heller ikke i Cæciliaforeningen har Henrik Rung fundet anledning til at opføre værket; først fra 1884 - altså knap 15 år efter stifterens død og efter at dirigentstokken først havde været $\mathrm{i}$ hænderne på Holger Paulli og siden på Henriks Rungs søn Frederik - kom det af og til på foreningens programmer: Thranes bog, der omfatter foreningens historie frem til 1901, nævner fire opførelser af Missa solemnis: 113. koncert 27. marts 1884 (Frue Kirke), 114. Koncert 13. november 1884 (Slotskirken), 157. koncert 12. april 1897 (sted ikke angivet), samt 158. koncert 22 november 1897 (sted ikke angivet). ${ }^{27}$ På dette tidspunkt var der sket en vis drejning i foreningens programpolitik, således at også musik fra de seneste 150 år efterhånden vandt indpas i foreningens koncertrepertoire. Om disse opførelser af Missa solemnis fandt sted efter vores manuskript, lader sig ikke afgøre. Det skal dog understreges, at partituret ikke

\section{H. \& Fr. Rungs Musik-Arkiv.}

Partitur.

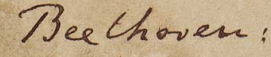
Dienee D-den

No $24 \cdot \sqrt{3}$.

Ill. 4: Frederik Rungs registrering af Beethovens manuskript $i$ hans katalog over $H$. \& Fr. Rungs Musikarkiv, påbegyndt i 1882. Som det ses, er verket her registreret som "Nr. 24 B".

bærer præg af at have været anvendt ved opførelser, ligesom der heller i samlingen findes stemmemateriale til værket.

Dette ændrer ikke ved, at værket siden Henrik Rung grundlagde sin samling $i$ 1830erne havde været en del af samlingen. Som nævnt, vides det ikke konkret, om han havde fundet manuskriptet ved et tilfælde på Christiansborg Slot blandt andre af det gamle Hofarkivs noder, eller om han ligefrem havde fået det forærende af kongen. Havde det sidste været tilfældet, måtte man formode, at der forelå en eller anden form for dokumentation. ${ }^{28}$ Heller ikke den store katalog over Rungs samling, som påbegyndtes i 1882 kaster lys over de her rejste usikkerhedspunkter. Den nummererede registrant blev iværksat efter Henrik Rungs død af sønnen, pudsigt nok på Gades foranledning, på trods af, at der havde været et stærkt modsætningsforhold mellem Gades Musikforeningen og Henrik Rungs Cæciliaforeningen - et modsætningsforhold, som dog blev løst efter Henrik Rungs død.

Registranten blev som nævnt påbegyndt i 1882 og fortsatte frem til 1914 
med $i$ alt knap 3.000 værker. I den oprindelige del af registranten er Missa solemnis opført i B-delen som nr. 24 - oprindeligt kun anført med komponistens navn, efterfølgende suppleret med blyantstilføjelsen Messe. D, men i øvrigt uden oplysninger om manuskriptets proveniens. ${ }^{29}$ Efter Frederik Rungs død i 1914 overgik den store samling med tilhørende registrant til Frederiks nevø, organisten P.S. Rung-Keller, som i 1955 overdrog den til Det Kongelige Bibliotek, hvor den siden har udgjort en af bibliotekets vigtigste samlinger af "ældre" musik - herunder genstanden for nærværende artikel.

Vi kan således sammenfatte hovedstationerne på manuskriptets vej fra værkets tilblivelse frem til i dag således:

1819-1822 Beethoven komponerer Missa solemnis

Januar 1823 Beethoven og Schindler udformer subskriptionsskrivelser til fyrstehofferne

Foråret 1823 Beethoven lader kopieringen af en række eksemplarer foretage, herunder den kopi, der senere tilgik Frederik 6.

Foråret 1824 Subskriptionsskrivelse til Frederik 6. afsendes

Efteråret 1824(?) Det af Beethoven gennemsete og rettede eksemplar sendes til Frederik 6. i København

1826 (?) Manuskriptet indlemmes i hoffets nodesamling, men "mangler" i Hofkatalogen fra 1826

1830erne (?) Værket indlemmes i Henrik Rungs nodesamling og er muligvis et af de manuskripter, som Rung finder på loftet af Christiansborg Slot

1882 Værket indføres i Frederik Rungs håndskrevne katalog over $H$.ぬ Fr. Rungs Musikarkiv

1955 Manuskriptet overføres til Det Kongelige Bibliotek på organist Rung-Kellers foranledning sammen med den øvrige del af det omfattende H. Fr. Rungs Musikarkiv

1996

Manuskriptet påkalder sig Beethoven-forskningens opmærksomhed i forbindelse med kildesøgningen forud for udgivelsen af det pågældende bind i den samlede udgave af Beethovens værker. ${ }^{30}$

Manuskriptet anføres som kilde $\mathbf{D}^{6}$ i Beethoven, Werke, Abteilung VIII, ed. Norbert Gertsch.

$I^{2}$

det foregående har værket alene været omtalt som dokument - altså dets proveniens og historie. Afsluttende skal dets betydning som kilde - altså manuskriptets indhold - omtales ganske kort. Denne side af historien er grundig beskrevet i Norbert Gertsch's artikel, som er nævnt i indledningen til nærværende fremstilling, ligesom den er dokumenteret i det kritiske apparat i det relevante bind i 
den samlede Beethoven-udgave. Gertsch fremhæver følgende detaljer omkring den danske kopi:

- trombonestemmerne i størstedelen af værket er tilføjet partituret med rødt blæk - i Gloria- satsens t. 345-59 i Beethovens hånd (se ill. 5).

- syv forskellige kopister har været involveret i kopieringen.

- kopien er - ligesom de øvrige fem bevarede subskriptionskopier - foretaget efter Beethovens såkaldte Arbeitskopie. $^{31}$

Beethovens foretog angiveligt $i$ alt ca. 300 ændringer i manuskriptet både med blyant og med blæk, hvoraf langt de fleste har karakter af banale korrekturrettelser.

Syv af Beethovens ændringer har en sådan karakter, at de ifølge Gertsch “... not only shed light on the interdependence of the sources, but also clarify details and inconsistencies in the different editions of the Missa solemnis".

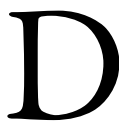
et, der giver den danske kopi en særstilling i forhold til de øvrige fem bevarede subskriptionskopier er det forhold, at leveringen til det danske hof trak ud i forhold til leveringen af kopier til de øvrige hoffer; herved fik Beethoven mulighed for at indføje rettelser i den danske kopi, som han først var blevet opmærksom på i forbindelse med den løbende revision af den omtalte Arbeitskopi og efter afsendelsen af de fem andre kopier.

Det er ikke her stedet at opregne Beethovens forskellige rettelser og tilføjelser - hvad de angår, henvises til Gertsch's artikel i Beethoven Forum. ${ }^{32}$ Derimod skal afslutningsvis understreges, at manuskriptet på enkelte punkter har været afgørende for en række detaljer i forbindelse med udgivelsen af messen $\mathrm{i}$ den samlede Beethoven-udgave i 2000, idet det skal bemærkes, at dens betydning i denne sammenhæng naturligvis slet ikke kan sammenlignes med Beethovens autograf, hans arbejdskopi, dedikationseksemplaret til ærkehertug Rudolf eller til trykforlægget, som blev sendt til trykkeren i Mainz i begyndelsen af 1825 - altså efter at hele aktionen med disse fyrstelige subskriptionseksemplarer var afsluttet. ${ }^{33}$ Blandt de mere afgørende korrektioner, som vores manuskript har bidraget til, skal anføres dels Beethovens egenhændige tilføjelse af tre tromboner i Gloria til teksten cum Sancto Spiritu in gloria Dei patri (t. 345 ff.), dels en ominstrumentering (på baggrund af Beethovens nu ulæselige autografe anvisning i partituret) i begyndelsen af Credo'et Et incarnatusafsnit (t. 124 ff.). Se ill. 5 og ill. 6.

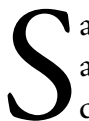
ammenfattende kan vi konstatere, at selvom Beethovens ændringer (og dermed manuskriptets værdi som kilde) er "interessante", om end - med et par undtagelser - ikke "epokegørende", belyser selve manuskriptets historie en væsentlig side af lanceringen af et af den sene Beethovens mest spektakulære værker; hvortil kommer, at manuskriptet - altså det fysiske dokument, som i dag kan studeres på KBs læsesal - for mere end 175 år siden lå på Beethovens skrivepult, hvor han indførte en række rettelser og overstregninger før han sagde god for, at det måtte ekspederes til Danmark. Dette, kombineret med det forhold, at manuskriptet har henligget upåagtet $\mathrm{i}$ danske samlinger i årene mellem $1825 \mathrm{og}$ 1996 samtidig med, at vi med en enkelt 


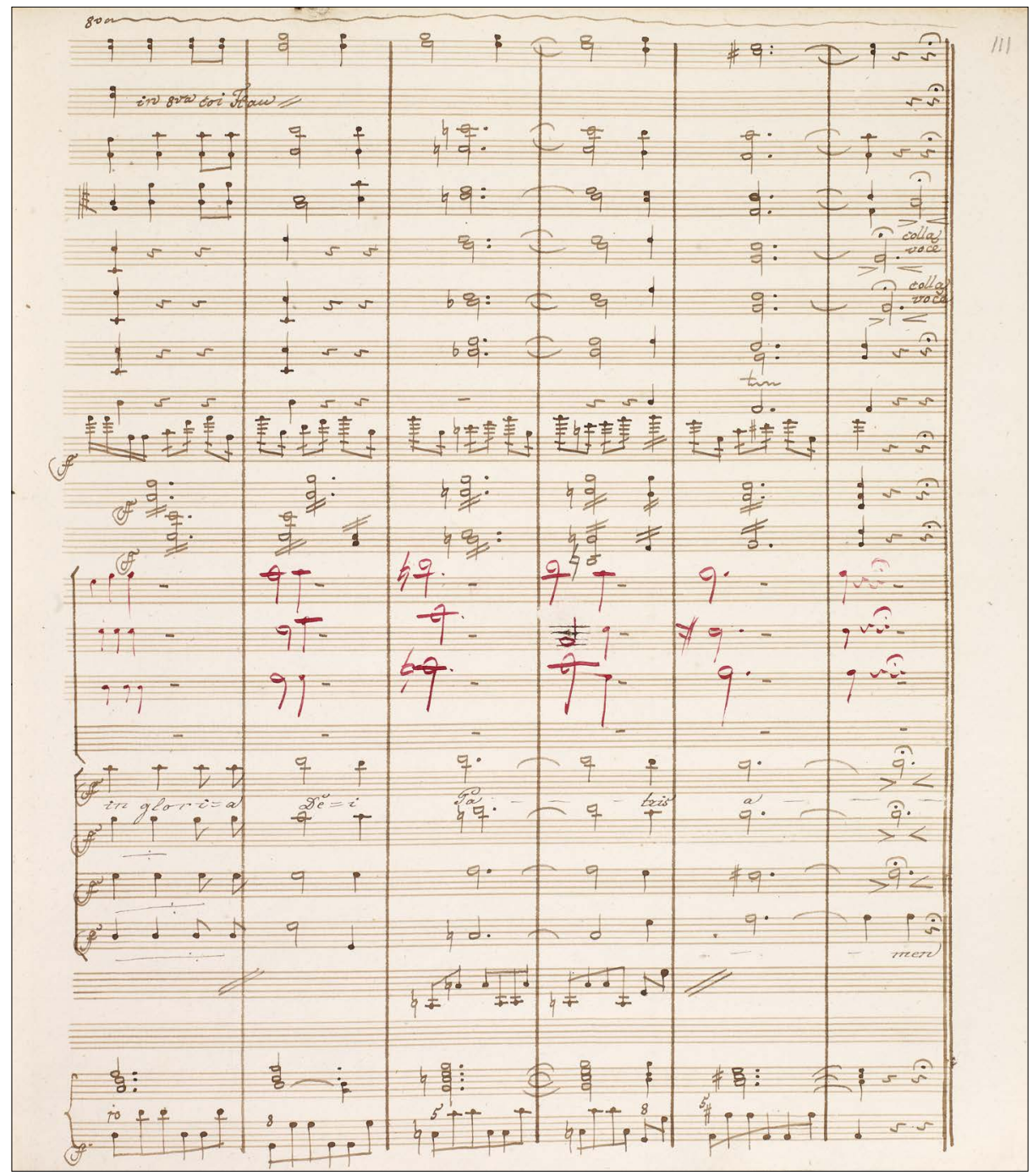

Ill. 5: Kopi af Missa solemnis, Gloria-satsen side 111, med Beethovens egenhendige tilfojelser af de tre trombonestemmer.

undtagelse kan følge dets vej fra Wien til København, gør det berettiget at karakterisere det som et af musiksamlingens klenodier.

Ovenstående redegørelse skal således primært opfattes som en analyse af selve manuskriptets historie, og kun sekundært som et bidrag til vores viden om Beethovens komposition. To vigtige detaljer mangler dog at falde på plads i denne lange fortælling. For det første: hvordan og ved hvis mellemkomst blev manuskriptet 


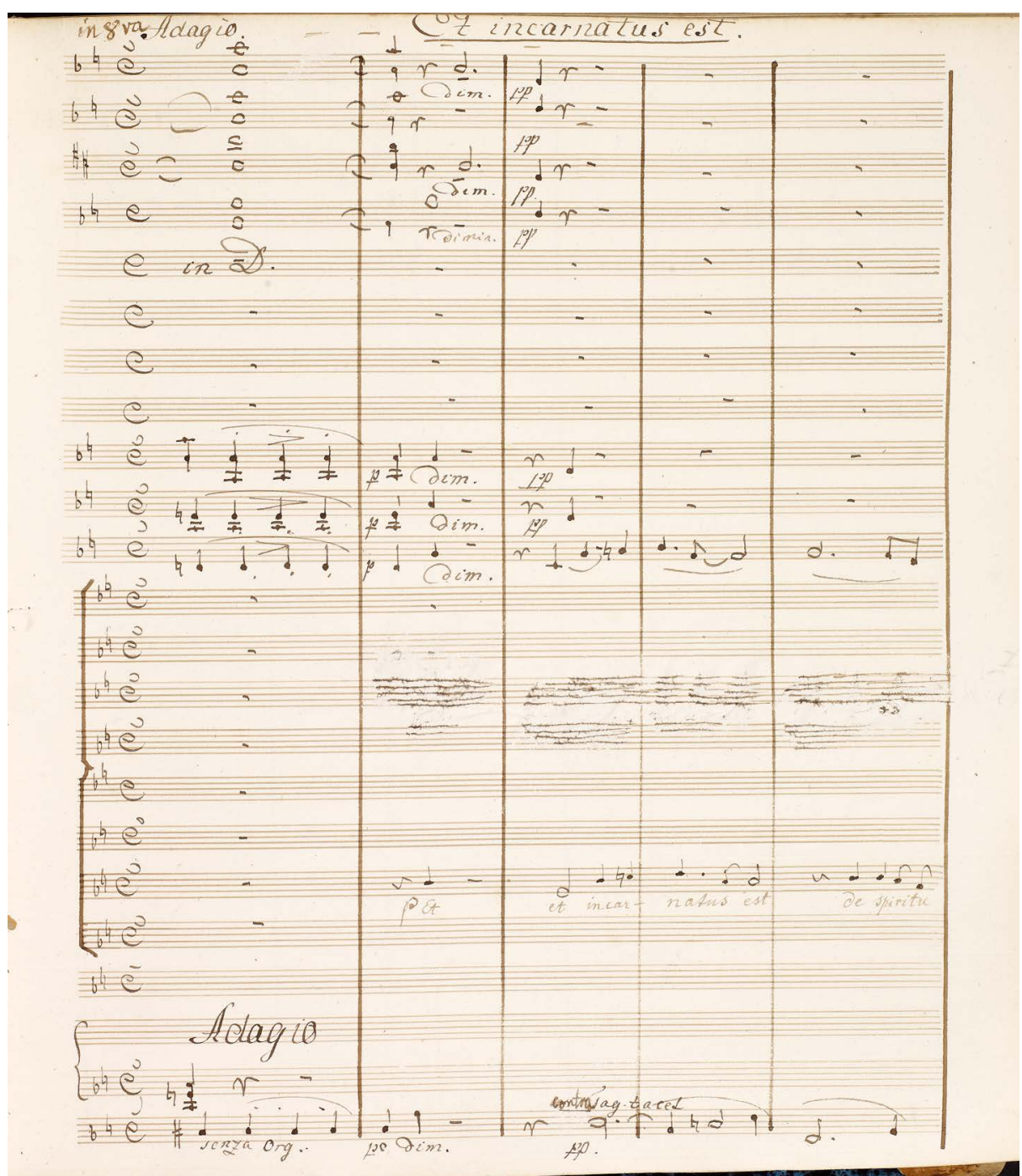

Ill. 6: Kopi af Missa solemnis, Credo-satsens Et incarnatus, med Beethovens egenhandige udradering af tenor-solistens stemme og en ulaselig anvisning om, at passagen skal flyttes til korets tenorstemme fire systemer lengere nede.

overført fra Wien til København i 1824? findes der et følgebrev eller et takkebrev? Og for det andet: hvor har manuskriptet befundet sig $\mathrm{i}$ årene mellem modtagelsen af værket i $1824 \mathrm{og}$ indlemmelsen i Henrik Rungs samling på et tidspunkt efter
1830 og, og hvordan er det kommet i Henrik Rungs besiddelse? Er han snublet over det på loftet af Christiansborg Slot, har han fået det som gave af Frederik 6., eller har han tilegnet sig det på en helt tredje måde? 


\section{Noter}

1 Katalog signatur: Rung Nr 24 B, C I, 628 $2^{\circ}, 1954-55.661$

2 Beethoven, Werke, Abteilung VIII, ed. Norbert Gertsch, München 2000.

3 Anledningen til nærværende præsentation er et tilfældigt opslag i mit private eksemplar af Beethoven Forum, Vol. 6, University of Nebraska Press 1998, hvori udgiveren af Missa Solemnis i Beethoven-udgaven, Norbert Gertsch, har skrevet en artikel med titlen "A Subscription Copy of Ludwig van Beethoven's Missa solemnis Opus 123, for King Frederik VI of Denmark", byggende på et besøg i Det Kongelige Bibliotek i midten af 1990erne. En del af empirien i nærværende artikel tager således udgangspunkt i Gertsch's artikel, idet der dog er foretaget en række tilføjelser og uddybninger af forskellig art. Historien om det danske eksemplar er også kort fortalt i kildebeskrivelsen i udgaven af værket i den samlede Beethoven-udgave (se note 2).

4 Anton Schindler, Biographie von Ludwig van Beethoven, (3. udgave 1860) Reclam 1977, s. 298 ff; Ludwig van Beethovens Leben von Alexander Wheelock Thayer [...] weitergeführt von Hermann Deiters, Vierter Band, Leipzig 1907, bd. 4, s. 354 ff., specielt s. 370 .

5 Som det fremgår nedenfor, vaklede Beethoven mellem flere varianter af titlen på sit nye værk. Kompositionen voldte ham store vanskeligheder, hvilket bl.a. viser sig deri, at det oprindeligt var tænkt til ærkebispeindvielsen af ærkehertug Rudolf i marts 1820, altså tre år før messen rent faktisk var færdigkomponeret.

6 Beethoven. Briefwechsel, Gesamtausgabe, bd. 5, 1996, Brief 1525, Beethovens subskriptionsskrivelse til en række europæiske fyrstehuse, heriblandt formentlig også den danske konge, Frederik 6., jf. nedenfor.

7 I sidste ende kom indtjeningen næppe til at svare til Beethoven oprindelige forvent- ninger. I alt indkom ti subskriptioner à 50 dukater; når man medtænker udgifterne til at få kopieret disse eksemplarer og eventuelle udgifter til forsendelse med kurer, eller hvordan det nu er foregået, har det samlede overskud af forretningen næppe været overvældende.

8 "Beethoven führte nämlich den lange erwogenen Plan aus, die neue Messe sämtlichen grossen und kleinen Höfen auf Subskription im Manuskript anzubieten und für jedes Exemplar ein Honorar von fünfzig Dukaten festzustellen. Die Besorgung dieses mit vielen Formalitäten und Umständen verknüpften Geschäftes hatte er ganz in meine Hände gelegt. In dem deutschen Einladungsschreiben bezeichnete er dieses Werk als sein gelungenstes, in dem aber an den französischen Hof abgegangenen hieß es l'oeuvre le plus accompli, das vollendeste; in sämtlichen stand die ausdrückliche Bemerkung, daß das Werk auch als Oratorium gebraucht werden könne, das wollte heißen: im Konzertsaal". Citeret efter Anton Schindler, op. cit., s. 297-298.

9 "Mit Ausnahme des Exemplars für den König von Dänemark wurden diese Kopien [de øvrige fem bevarede subskriptionseksemplarer] gar nicht oder sehr oberflächlich von Beethoven gegengelesen" (Beethoven, Werke, op. cit., s. x).

10 Thayer, op. cit., s. 370.

11 Betagende udtrykt allerede i det såkaldte "Heiligenstadt-testamente" fra oktober 1802 (dvs. Beethovens brev til sine to brødre, hvori han fortæller om sit sørgelige liv, herunder sin dårlige hørelse).

12 Dagmar Beck og Grita Herre, "Einige Zweifel an der Ûberlieferung der Konversationshefte", i: Bericht über den Internationalen Beethoven-Kongress Berlin 1977, Leipzig 1978, s. 257-269. Undertegnede overværede selv denne afsløring på den nævnte kongres og oplevede den bestyrtelse, som affæren vakte hos de mange til- 
stedeværende Beethovenforskere, der her fik rokket ved deres billede af Schindler som et af de vigtigste og mest troværdige sandhedsvidner i forhold vedrørende Beethoven.

13 Det skal i denne forbindelse understreges, at netop de år, som nærværende artikel omhandler, nemlig årene 1823-24, er år, hvor man ikke har konstateret væsentlige forfalskede indførsler af Schindler.

14 Ifølge Norbert Gertsch, op. cit., note 14.

15 Den fyldigste omtale af Fürst findes i Sven Hakon Rossel, "Nikolai Nathan Fürst - ein Däne in Wien" (Text \& Kontext: Zeitschrift für germanistische Literaturforschung in Skandinavien, Vol. 26, Heft 1, München 2004, s. 14-35). Forfatteren slutter sin fremstilling således: "Vor allem aber ist bemerkenswert, dass ein eher unbekannter, nach Wien ausgewanderter Däne namens Nicolai Nathan Fürst sich so intensiv und systematisch bemüht hat, sowohl in Wiener Zeitungen und Zeitschriften als auch in selbständigen auf Deutsch verfassten Publikationen, die Kenntnisse über dänische Literatur und Autoren - bekannte wie unbekannte - zu verbreiten”. Hertil kan føjes, at dette øjensynligt skete i et sådant omfang, at også Beethoven blev opmærksom på det eller i hvert fald Schindler.

16 Ifølge uspecificeret oplysning i Gerhard Schepelern, Giuseppe Siboni. Et Afsnit af Operaens Historie ude og hjemme, København 1989, s. 227.

17 Jens Engberg, Den standhaftige tinsoldat. En biografi om Frederik 6, København 2009, s. 411.

18 Jeg har i anden sammenhængt gjort nøjere rede for disse kataloger, se min artikel "Simoni dall Croebelis - Compositeur ved Musiquen' - København 1787”, Musik og Forskning 2, København 1976, s. 56-65.

19 F.eks anføres Matthison-Hansens Paaskekantate fra 1848.
20 Såfremt denne indførsel skulle have dækket over "vores" Missa solemnis, er instrumentationen, som det fremgår, stærkt mangelfuld: hos Beethoven er der yderligere 2 horn, 2 fløjter, 2 klarinetter, 2 fagotter, pauker og vokal solister; allerede dette peger på, at Hofkatalogens værk intet har at gøre med Beethovens messe.

21 Indførslen i vedrørende maleriet lyder således i konversationshæftet (hæfte 11, 1-14 april 1820, altså fire år før de forskellige manuskripter til værket var færdigskrevet):

Stieler: "Aus welchem Tone geht ihre Messe ich mögte blos auf das Blat schreiben Messe aus."

Beethoven: "Missa solemnis aus D" Stieler: "eine Virtelstunde nach der Ausstellung werde ich es [altså maleriet] an die Brentano schücken. Ich danke Ihnen tausend und tausend-mahl für so viele Geduld".

22 Gieddes Samling XI,7, mu 6307.1850. I det hele taget er titlen "Missa solemnis" ikke ualmindelig i værker både før og efter Beethovens værk; alene fra bibliotekets samlinger kan nævnes Mozart, Reissiger, Caldara, Cherubini, Listz, og Bruckner.

23 Henrik Rungs musiksamling og dens betydning for dansk musikhistorie er beskrevet i John Bergsagel, "Henrik Rung - 'a feeling for music libraries", Fund og Forskning 43 (2004), s. 381-393. Vedr. Cæciliaforeningen henvises til Carl Thrane, Ceciliaforeningen og dens Stifter, København 1901.

24 Carl Thrane, Op. cit. s. 154.

25 Der er tale om Glucks “Serenata”, skrevet i anledning af Christian 7. fødsel; manuskriptet (KB, mu 6308.0660) dateret 12.3.1749 og opført i København på Charlottenborg d. 9. april samme år. Oprindeligt en del af Gieddes Samling, som senere indgik som en del af i hofarkivet, altså samme arkiv, som vi må formode har indeholdt vores Beethoven-manuskript, 
uden at dette dog på nogen måde har kunnet godtgøres i forbindelse med nærværende undersøgelse.

26 Heller ikke Carl Thrane omtaler med et ord Beethoven i sin bog.

27 Carl Thrane, op.cit., s. $229 \mathrm{ff}$.

28 Gennemgang af dele af Henrik Rungs og Ceciliaforeningens arkiver i KBs Håndskriftsafdeling har ikke kastet lys over dette spørgsmål.

29 Katalogen (skrevet med blæk i en folioprotokol fra firmaet Axel E. Aamodt, Kongens Nytorv 16) med titlen Katalog ordnet efter Numrene. Marts 1882 opbevares i bibliotekets musiksamling.

30 Forud for 1996 havde et evt. dansk subskriptionseksemplar, så vidt jeg ved, ikke været nævnt noget sted i sekundærlitteraturen ved siden af de øvrige kendte ni sådanne subskriptionseksemplarer (hvoraf de tre er gået tabt).

31 Denne arbejdskopi - og ikke Beethovens autograf - dannede udgangspunkt for Beethovens senere Stichvorlag og er dermed også hovedkilden for udgaven af messen i den samlede Beethoven udgave.

32 Norbert Gertsch, op. cit., s. 195 ff.

33 Værket forelå først trykt i slutningen af marts eller begyndelsen af april 1827, og Beethoven nåede ikke se det færdige tryk og har naturligvis således heller ikke kunnet læse korrektur på den trykte udgave, hvorfor denne som primær kilde kan lades ude af betragtning. 


\section{Indkaldelse af ansøgninger til \\ Frimærkehandler og jernbanehistoriker Peer Olav Thomassens Fond}

\section{Ansøgningsfrist: I. april 2014}

Fonden, som er stiftet i 1992, har formålet "Videreførsel af forskningen i fortrinsvis dansk trafik- og kommunikationshistorie" og yder støtte til:

a. Anskaffelse af relevant materiale, herunder til den fornødne bevaring, registrering, katalogisering, indbinding, konservering mv. af det indgåede materiale.

b. Udarbejdelse af publikationer, først og fremmest trykomkostninger.

c. Studie- og forskningsudgifter, herunder rejsetilskud.

d. Tilskud til afholdelse af udstillinger, seminarer, kongresser m.v.

Ad a: Støtte til opbygning af private bogsamlinger falder uden for formålet.

Ad c: Da fondens midler er af forholdsvis beskeden størrelse, vil det ikke være muligt at yde effektiv støtte til forskning inden for de i formålsparagraffen nævnte områder i form af løn.

Af hensyn til ekspedition af imødekomne ansøgninger, skal disse indeholde oplysning om modtagerens adresse og personnummer. Hvis ansøgeren er en juridisk person, skal man i ansøgningen oplyse CVR-nummer.

Ansøgning vedlagt curriculum vitae, eventuel publikationsliste samt anbefalinger stiles til direktør Erland Kolding Nielsen og sendes til:

\section{Det Kongelige Bibliotek}

elektronisk: kb@kb.dk

eller fysisk: Postboks 2149

1016 København K

så den er biblioteket i hænde senest 1. april 2014 med morgenposten / kl. 12:00.

Uddelingen forventes at finde sted i maj-juni 2014. 